\title{
DERAJAT KESEHATAN KUCING LIAR (Felis catus) MELALUI PEMERIKSAAN FUNGSI LIVER (SGPT AND SGOT) DI PASAR KECAMATAN TEGALSARI KOTA SURABAYA
}

\author{
Roeswandono $^{1}$, Lailia Dwi Kusuma Wardhani ${ }^{1}$, Nicodemos Borges Lonai ${ }^{1}$, Era Hari Mudji Restijono ${ }^{1 *}$ \\ ${ }^{1}$ Fakultas Kedokteran Hewan, Universitas Wijaya Kusuma Surabaya. \\ *Email: era.hari@yahoo.com.
}

\begin{abstract}
The present research aims to know Stray cat health status in the Tegalsari sub-district market in Surabaya. This type of research is a descriptive study, experimental animals used were 30 stray cats on the market. Through examination of the liver function SGOT and SGPT. Blood serum Collection of Stray cat in three markets in central of Surabaya city, specifically in Tegalsari subdistrict, namely the pasar kembang, pasar keputran selatan and pasar keputran utara, blood serum of 10 cats (Stray cat) taken from each market as much as $3 \mathrm{ml}$ to test the SGPT and SGOT value, Data analysis using Analysis of Variant (ANOVA) the average SGOT value were $43.8+12.9 \mu / \mathrm{l}$ in pasar kembang, $79.0 \pm 50.3 \mu / l$ in pasar keputran selatan and $47.7 \pm 12.3 \mu / l$ in pasar keputran utara and average $S \overline{G P T}$ value were $98.0 \pm 48.7 \mu / \mathrm{l}$ in the pasar kembang, 119.9+83.6 $\mu / \mathrm{l}$ pasar keputran selatan and 103,9 $\pm 40.6 \mu / l$ pasar keputran utara. The SGOT value significantly different $(P<0.05)$ while the SGPT value was not significantly different $(P>0.05)$. The value of SGOT and $S G P T$ in pasar keputran selatan was higher compared to the pasar keputran utara and the pasar kembang.
\end{abstract}

Keywords: Stray cat, blood serum, SGOT, SGPT.

\section{PENDAHULUAN.}

Stray cat hidup secara liar di jalanan. Untuk mempertahankan hidupnya Stray cat harus mencuri makanan atau mengacakngacak tempat sampah dan tidur dimana saja (Spotte 2014). Stray cat juga harus saling terjang demi memperebutkan jatah makan atau jatah sahwat. Bahkan jalanan bisa lebih buas bagi kucing daripada hutan belantara. (Madyantari et al., 2016). Kondisi tubuh yang kotor bahkan berpenyakit selama hidupnya sudah terbiasa untuk kucing jalanan (Stray cat) (Kusumawati dan Sardjana 2009). Permasalahan kucing menjadi masalah yang cukup serius di Indonesia. Lebih dari 50.000 anak kucing lahir setiap harinya (Hildreth, et al., 2010). Dari sekian banyak kucing ini hanya $1 / 5$ nya yang bisa mendapatkan rumah, sisanya berkeliaran secara liar, terabaikan atau mendapat perlakuan kasar. Setiap tahunnya, 6-8 juta kucing masuk penampungan hewan dan sekitar setengahnya (3-4 juta) harus di Euthanasia (mempercepat kematian seseorang dalam kesakitan dan penderitaan hebat menjelang kematian) karena tidak ada yang ingin memelihara mereka. (Lawhead dan Baker, 2010)
Pemeriksaan tes fungsi hati diperlukan guna membantu dalam diagnosis dokter terhadap hewan, terutama hewan yang mengalami dengan gangguan fungsi hati (Reza dan Rachmawati, 2017). Pemeriksaan tes fungsi hati yang diperlukan meliputi pemeriksaan yang spesifik terhadap inflamasi parenkim hepar yaitu, Serum Glutamic Oxaloacetic Transaminase (SGOT) atau Aspartarte aminotransferase (AST) dan Serum Glutamic Piruvic Transaminase (SGPT) atau Alanine aminotransferase (ALT) bertujuan untuk mengetahui inflamasi yang terjadi dalam tubuh dan biasanya menjadi indikasi adanya gangguan (inflamasi) pada hati (Schalm, 2010).

\section{MATERI DAN METODE.}
Alat dan bahan.
Peralatan yang digunakan dalam pengambilan sampel darah kucing domestik yang berkeliaran di pasar adalah : Spuit $3 \mathrm{cc}$, tabung venoject non EDTA, cool box, alkohol $70 \%$, dan kapas. Hewan coba yang digunakan dalam penelitian ini kucing domestic yang berkeliaran di pasar (Stray cat) sebanyak 30 ekor yang ada di pasar Kecamatan tegal sari, Surabaya, Jawa Timur, dan mengunakan reagen SGOT dan reagen SGPT. 


\section{Metode}

Prosedur Penelitian dalam penelitian ini menggunakan 30 ekor kucing domestic yang berkeliaran di pasar (Stray cat). Kucing jalanan yang ada di pasar ditangkap lalu mengambil sampel darah dan dimasukan di tabung Venojec non EDTA dan kucing yang sudah ambil darah diberi tanda, setelah kasih tanda kucing tersebut dilepas kembali.

\section{HASIL}

Tabel 1.Nilai rata-rata SGOT Stray cat di pasar kembang, pasar keputran selatan dan pasar keputran utara.

\begin{tabular}{ccc}
\hline No & Nama pasar & $\begin{array}{c}\text { Mean } \pm \text { SD } \\
(\mu / 1)\end{array}$ \\
\cline { 3 - 3 } 1 & PasarKembang & $43,8 \pm 12,9$ \\
\hline 2 & PasarKeputran Selatan & $79,0 \pm 50,3$ \\
\hline 3 & PasarKeputran Utara & $47,7+12,3$ \\
\hline
\end{tabular}

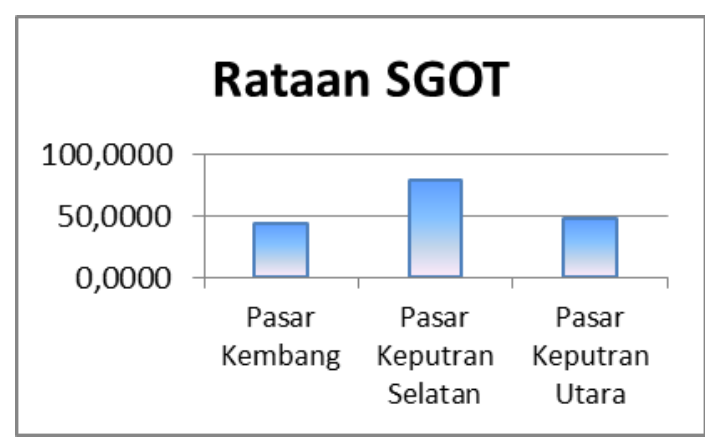

Gambar 1. Diagram nilai SGOT pada Stray cat di pasar kembang, pasar keputran selatan dan pasar keputran utara.

Tabel 2. Nilai rata-rata SGPT Stray cat di pasar Kembang, pasar keputran selatan dan pasar keputran utara.

\begin{tabular}{ccc}
\hline No & Nama pasar & $\begin{array}{c}\text { Mean+ SD } \\
(\mu / 1)\end{array}$ \\
\cline { 3 - 3 } 1 & Pasar Kembang & $98,0+48,7$ \\
\hline 2 & Pasar Keputran Selatan & $119,9+83,6$ \\
\hline 3 & Pasar Keputran Utara & $103,9+40,6$
\end{tabular}

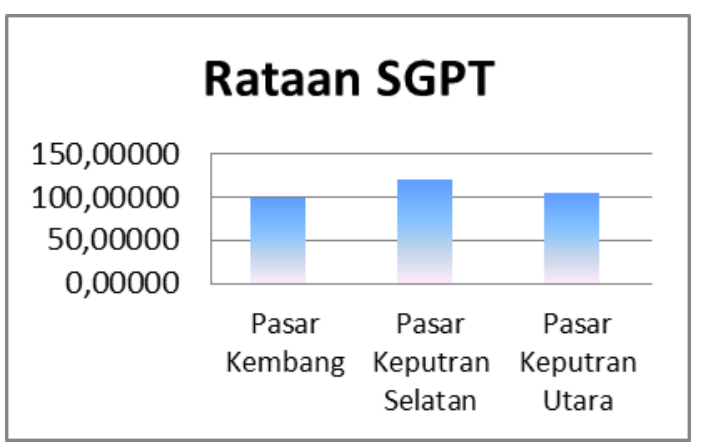

Gambar 2. Diagram nilai SGPT pada Stray cat di pasar kembang, pasar keputran selatan dan pasar keputran utara.

\section{PEMBAHASAN}

\section{Serum Glutamic Okaloasetic Transaminase (SGOT).}

Dari hasil penelitian yang diperoleh diketahui bahwa rata-rata nilai SGOT pada Stray cat dipasar Kemabang 43,8 $\pm 12,9 \mu / 1$, pasar Keputran selatan $79,0+50, \overline{3} \mu / 1$ dan pasar keputran utara 47,7 $\pm 12,3 \quad \mu / 1$ menunjukan adanya perbedaan nyata $(\mathrm{P}$

$<0,05)$ dan dilihat dari diagram SGOT pada Stray cat di pasar keputran selatan dinyatakan lebih tinggi disbanding pasar keputran utara dan pasar kembang sedangkan nilai normal SGOT pada kucing yaitu 8,9-48,5 $\mu / 1$ (Schalm, 2010).

Peningkatan nilai total SGOT mengindikasikan adanya gangguan pada sistem hepatobiliary, Feline Hepatobiliary Disease dapat disebabkan oleh hepatic lipidosis, inflammatory liver disease, lymphoma, Feline Infectious Peritonitis, acute hepatocellular necrosis (Al-Ani, 2018).

\section{Serum Glutamic Pyruvic Transaminase (SGPT).}

Dari hasil penelitian yang diperoleh diketahui bahwa rata-rata nilai SGPT pada Stray cat dipasar kembang 98,0 $\pm 48,7 \mu / 1$, pasar keputran selatan $119,9 \pm 83,6 \mu / 1$ dan pasar keputran utara 103,9 $\pm 40,6 \mu / 1$ menunjukan tidak adanya perbedaan nyata ( $\mathrm{P}$ $>0,05)$ dan di lihat dari diagram SGPT pada Stray cat dipasar keputran selatan dinyatakan lebih tinggi dibanding pasar keputran utara dan pasar kembang sedangkan nilai normal 
SGPT pada kucing yaitu8,2-57,3 $\mu / 1$ (Schalm, 2010).

Penyakit liver pada kucing (Stray cat) menunjukan peningkatan serum SGPT dan SGOT karena enzim bocor dan berkembang cepat dalam serum dalam beberapa jam (Center, 2010). Sementara enzim yang diinduksi memerlukan berhari-hari stimulasi produksi enzim yang diinduksi dan kebocoran enzim hanya terjadi dalam perubahan selaput sel atau sel yang cedera yang dapat melepaskan ke dalam serum dan juga mungkin membran terdapat retak kemudian menyebabkan peningkatan aktivitas kebocoran enzim (Al-Ani, 2018).

Enzim SGOT dan SGPT berhubungan dengan parenkim sel hati, perbedaannya, SGPT ditemukan lebih banyak di hati, (secara klinis jumlah konsentrasi rendah diabaikan dan ditemukan di ginjal, jantung, dan otot rangka), sedangkan SGOT ditemukan dalam hati, jantung (otot jantung), otot rangka, ginjal, otak, dan sel darah merah, oleh karena itu, SGPT merupakan indikator yang lebih spesifik pada peradangan hati daripada SGOT. SGOT dapat meningkat pada penyakit yang dapat mempengaruhi organ-organ lain, seperti infark miokard, pancreatitis akut, anemia hemolitik akut, luka bakar parah, penyakit ginjal akut, penyakit muskuloskeletal, dan trauma (Reza dan Rachmawati, 2017).

Faktor-faktor yang mempegaruhi peningkatannya SGPT dan SGOT pada Stray cat seperti sejumlah racun yang ada di lingkungan, penyakit infeksi dan bahan tambahan pangan, sejumlah racun yang ada di lingkungan termasuk aflatoksin, jamur Amanita, biji cycad, dan ganggang biru hijau, menyebabkan kegagalan fungsi hati yang sangat akut, Aflatoksin adalah senyawa toksik yang diproduksi oleh Aspergillus flavus, jamur saprofitik (Cortinovis dan Caloni 2016) Hepatotoksikosis biasanya terjadi setelahnya konsumsi makanan yang mengandung jagung berjamur. Penyebab penyakit infeksi hati termasuk virus, protozoa, bakteri, dan agen jamur serta infeksi cacing hati, Penyakit virus (termasuk infeksi hepatitis anjing dan FIP (Feline Infectious Peritonitis) (Rotoro dan Puspitasari 2014). Agen protozoa Toxoplasma dan Neospora spp. dapat menyebabkan ALF
(Center, 2010). Bahan tambahan pangan terlibat dalam hepatotoksisitas seperti xylitol, Stray cat dapat makan di jalan yang mengandung xylitol dan dapat menyebabkan kekurangan gula darah pada Stray cat dan dapat menyebabkan gagal fungsi liver (Cooper dan Webster, 2009).

\section{DAFTAR PUSTAKA}

Center S. A. 201., Feline Hepatic Lipidosis, Vet Clin Small Anim, College of Veterinary Medicine, Cornell University, 35 (2005) 225-269.

Cooper J dan Webster C. R. L., 2009., Acute Liver Failure. CE Article, Illustration by Felecia Paras Tufts University.

Cortinovis C danCaloni F (2016)., Household Food Items Toxic to Dogs and Cats. Department of Health, Animal Science and Food Safety, Universitá degli Studi di Milano, Milan, Italy Front. Vet. Sci. 3:26. doi: 10.338 .

Hildreth AM., M Stephen. Vantassel, E Scott .Hygnstrom, 2010.Feral Cats and Their Management. University of Nebraska Lincoln.

Kovalkovicová N et all.,2009., Some food toxic for pets, InterdiscToxicol, vol. 2 2(3): 169 9-176. doi: 10.2478/v10102009-0012-4

Kozat dan Sepehrizade., 2017., Methods of diagnosis in liver disease for dog and cats, turkbilimselderlemerdergisi, Turkish journal of scientific, van yuzuncuyil university, faculty of veterinary.

Kusumawati D.dan Sardjana K. W. 2009., A Study of Different Palatable Foods for Stray cats, Bagian Klinik Veteriner, Fakultas Kedokteran Hewan, Universitas Airlangga, Surabaya.

Lawhead, J.B. and J.M. Baker.,2010., Introduction to Veterinary Science. Australia: Thomson and Learning.

Madyantari N. et all., 2016., Designing Illustration Book Of Stray cats In 
e-ISSN 2685-8894; p-ISSN 2460-9773

Jurnal Vitek Bidang Kedokteran Hewan Vol.9, November 2019

Bandung, Program Studi Desain Komunikasi Visual, Fakultas Industri Kreatif, Universitas Telkom.

Reza A. Dan Rachmawati B. 2017., Perbedaan Kadar Sgot Dan Sgpt Antara Subyek Dengan Dan Tanpa Diabetes Mellitus. Diponegoro Medical Journal (Jurnal Kedokteran Diponegoro) Vol.6 no.2, pp. 158-166.

Rotoro S. R. danPuspitasari S. 2014. StudiKasus Jaundice PadaKucing Dan Penanganan Terbaru Kasus Feline Infectious Peritonitis. Prosiding Konferensi Ilmiah Veteriner Nasional (KIVNAS).

Schalm, O.W., 2010., Veterinary Hematology. Ed ke-6. Philadelphia: Lea and Febiger.

Spotte S. 2014., Free-ranging Cats Behavior, Ecology, Management, first published by John Wiley \& Sons, Ltd, The Atrium, Southern Gate, Chichester, West Sussex, PO19 8SQ, UK. 